\title{
ARTIGOS
}

\section{CEMENT CONTENT REDUCTION IN CONCRETE THROUGH AGGREGATE OPTIMIZATION AND PACKING: A SUSTAINABLE PRACTICE FOR PAVEMENT AND SEAPORT CONSTRUCTION}

RODRIGO ANTUNES, Ph.D. | UNIVERSITY OF FLORIDA, USA

MANG TIA, Ph.D. | UNIVERSITY OF FLORIDA, USA

\begin{abstract}
Based on the full-bodied scientific consensus that climate warming is occurring on Earth, significant environmental and economic benefits may be obtained from cement content reduction in concrete, naming reduction in $\mathrm{CO} 2$ emissions, energy consumption, and construction costs. In contrast, standard limestone aggregate may experience an increase in mining rate. The objective of this study was to propose the reduction of cement content in concrete framed by aggregate optimization as a viable alternative to reduce environmental effects from the cement industry. The study concludes that the higher the concrete volume in construction, the more environmental benefit can be obtained by reducing cement content in concrete. A $25 \%$ cement reduction in a concrete pavement led to a decrease of 80.000 tons in $\mathrm{CO} 2$ emission, while a seaport construction displayed a decrease of 17.000 tons of $\mathrm{CO} 2$. The higher the designed cement per volume of concrete, the more budget savings in case of reduction in cement content. Port construction presented a reduction of 20,10 USD per m3 of concrete in cement costs against 11,04 USD per $\mathrm{m} 3$ in pavements. An 11,5\% increase in aggregate mining is expected when concrete contains less cement in its composition, targeting South Florida (U.S.A.) quarries.
\end{abstract}

KEY WORDS: Aggregate optimization; Concrete; $\mathrm{CO} 2$; Infrastructure; Sustainability 


\section{INTRODUCTION}

Scientists through a robust scientific consensus claim that warming of the climate system is occurring on Earth. The Intergovernmental Panel on Climate Change (IPCC), in the Fifth Assessment Report (AR5) released in 2013, affirms that climate change is unequivocal. The report confirms that atmosphere and ocean have warmed up, the amounts of snow and ice have decreased, the mean of global sea level has increased, and the accumulation of greenhouse gases (GHG) has raised. Continued GHG emissions may generate more warming in the climate system, and a large reduction of GHG is needed to restrain climate changes, preventing drastic consequences to society and environment (NEC, 2016).

Infrastructure has a significant effect on climate change. It accounts for more than $60 \%$ of the GHG emissions. Sustainable infrastructure is crucial for society to adapt to the climate effects. Technological advances in Civil Engineering materials lead to higher efficiency in the use of natural resources and energy, which is an urgent challenge (NEC, 2016).

Cement and concrete industry is a significant contributor to Carbon Dioxide (CO2) emissions and environmental degradation. As such, efforts have been made to cut the $\mathrm{CO} 2$ footprint of the final products. One of the primary measures partially implemented by the industry, including the cement producers, ready-mix concrete companies, and construction firms, is the rational use of natural resources. The rationale is: the lower the cement content and natural aggregate consumption in concrete, the lower the negative impact on the environment is supposed to be (Khatibmasjedi, De Caso y Basalo, and Nanni, 2016; Mehta 2002). While demand for new infrastructure remains strong worldwide, finding technical and environmentally sound solutions is a priority for delivering Sustainable Development Goals (SDG) and reducing climate risk (NEC, 2016).

Materials, water, and energy consumption in concrete production became a crucial aspect of the entire supply chain. Thus, adopting sustainable techniques while keeping the concrete properties at high standard levels is essential towards better resources management (Agopyan and John, 2011; Khatibmasjedi, De Caso y Basalo, and Nanni, 2016). Portland cement production is not only energy-intensive but also responsible for significant emissions of $\mathrm{CO} 2$ (MEHTA, 2002). Consequently, lower $\mathrm{CO} 2$ emissions would also be observed not just due to the decrease in raw materials extraction, but also by reducing the energy required to process the resources (Agopyan and John, 2011; Aissoun, Hwang, and Khayat, 2016).
Nowadays, technological innovations have turned possible cement plants to operate at the $90 \%$ efficiency level due to higher equipment availability, lower energy consumption, and higher nominal efficiency of the equipment. For instance, pre-heating towers have been included in modern plant layouts. Also, renewable sources of energy have replaced coal by about $8 \%$ as a source of fuel for kilns. Companies have used recycled carpet, plastic, and paper to generate heat in kilns, as well as roughly 60 $\%$ of natural gas to run cement production (LACC, 2015).

Although companies have taken some efficient measures, more can be done to reduce environmental impacts. For this reason, this study investigates the influence of cement content reduction in concrete as a sustainable practice to reduce $\mathrm{CO} 2$ emission. A combination of aggregate optimization and packing is emphasized in typical real-world cases of slip-formed concrete for pavement, and concrete structures for port construction since these are essential infrastructure projects that usually need large volumes of concrete for suitable completion.

\section{BACKGROUND}

\subsection{Cement Production}

Despite industry efforts to address $\mathrm{CO} 2$ emissions, singular initiatives have low environmental significance. Thus, a joint effort must be made involving academia, government, policymakers, industry, and communities to create a sustainable production environment in which all stakeholders can be benefited (Agopyan and John, 2011).

Limestone is the primary component in cement production and is blended to aluminum, iron, and silica to form the so-called raw meal further burnt into a kiln at about $1300{ }^{\circ} \mathrm{C}$ to allow chemical reactions needed to produce clinker (IEA, 2010). At the end of the kiln, formed clinker usually passes through ball mills to achieve the appropriate Particle Size Distribution (PSD), then blended to $5 \%$ of gypsum. Figure 01 illustrates part of the cement production process.

One procedure largely adopted in modern cement plants to reduce energy consumption is the implementation of pre-heating towers into the production process. In general, raw materials pass through pre-heating towers for about 10 seconds, enough time to increase the raw material temperature from $100{ }^{\circ} \mathrm{C}$ to $870{ }^{\circ} \mathrm{C}$, approximately. Within this temperature range, most chemical reactions occur, thus reducing the time within rotational kilns (IEA, 2010). 


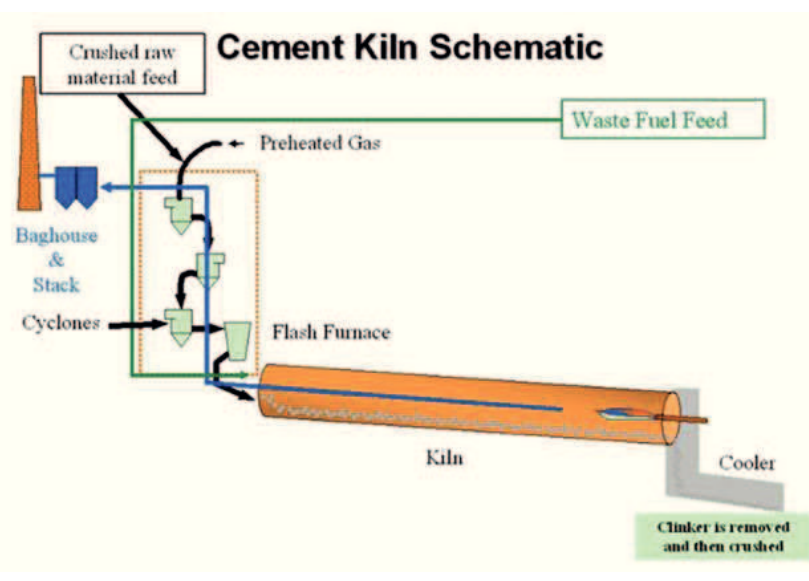

Figure 01 Simplified cement production process

Source: author.

\subsection{Aggregate Gradation}

Aggregate gradation is defined as the distribution of particles of a granular material among the various size ranges, usually expressed in cumulative percentage passing through standard sieve series. The Maximum Aggregate Size (MS) is defined as the smallest sieve size that retains $15 \%$ or more of the particles, and the fineness modulus (FM) of fine aggregates as the cumulative percentage of particles retained within the standard sieves $150 \mu \mathrm{m}$ and $37.5 \mathrm{~mm}$ (MEHTA AND MONTEIRO, 2006).

Most concrete mixtures are composed of: fine aggregate, with particles smaller than $4.75 \mathrm{~mm}$; and coarse aggregate, with particles larger than $4.75 \mathrm{~mm}$. A well-graded distribution, which is, covering all particle sizes, often contains a higher percentage of intermediate-sized particles and smaller portions at the extremes. Such gradation is often described as a haystack when plotted on percent retained charts (MEHTA AND MONTEIRO, 2006).

\subsection{Aggregate Optimization}

Optimized aggregate gradations have been specified and endorsed. In contrast, very few practical and comprehensive methods to perform the optimization are available to concrete practitioners (Lindquist et al., 2015).

The combination of coarse and fine aggregates is commonly not well-graded because of the absence of intermediate-sized particles. Figure 02 shows an example of a poorly-graded aggregate with a gap-graded or peak-valley-peak distribution (Lindquist et al., 2015), as well as haystack curve.

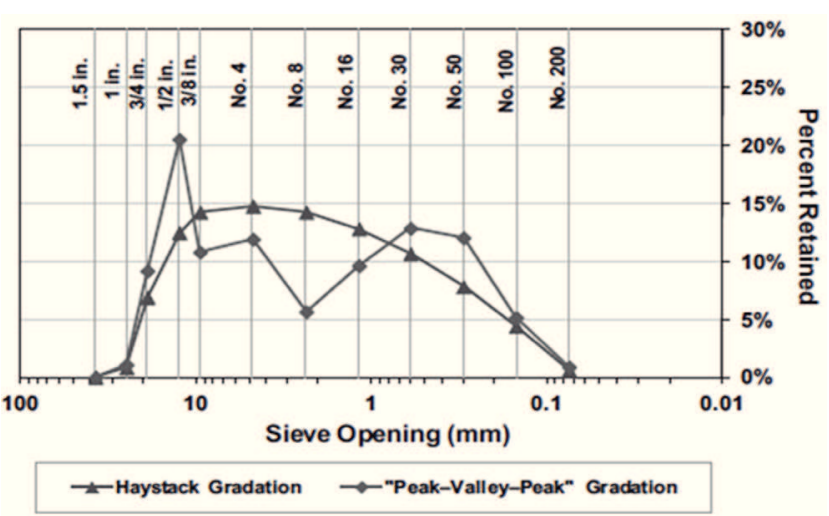

Figure $\mathbf{0 2}$ Haystack and a gap-graded peak-valley-peak gradations.

There are two conventional techniques to develop optimized aggregate gradations: the percent retained chart, and the Modified Coarseness Factor Chart (MCFC). The first step of the process is developing a target gradation that plots as a haystack on the percent retained chart (Lindquist et al., 2015).

\subsection{Aggregate Packing}

Historical data on packing come from Scandinavia as early as 1896 for providing concrete durability in marine environments. Most of the literature on packing was published in the 1930s describing the optimization of packing (Mohammed et al., 2012).

Fundamentals on aggregate packing have been the focus of scientific discussions for about a century (Moini et al., 2015). Figure 03a (Moini et al., 2015) shows monosized and random spherical particle shapes used in aggregate packing theoretical simulations. The well-known spherical simulations may generate fewer voids to fill with cement paste than empirical approaches, leading to optimistic results. Since spherical blends pack $12 \%$ more than crushed blends (Figure 03b) (De Larrard, 1999), computer simulations may predict use of $12 \%$ less cement paste content in concrete mixtures, which does not match to current practices regarding cement paste volume (De Larrard, 1999). (a)

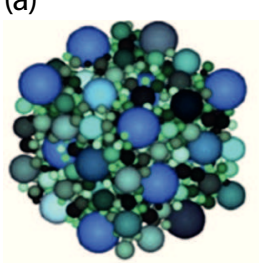

(b)

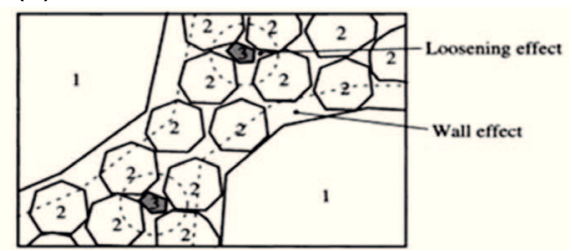

Figure 03 Aggregate models. (a) spherical, (b) crushed. Source: author. 
The definition of Aggregate Packing ( $k$ ) is the ratio between the actual Solids Volume (Pv) and the Compacted Bulk Volume (V). In any typical blend, packing depends on three main parameters: the size of the grains, the shape of the grains, and the packing method (De Larrard, 1999). The method depends on the energy applied to the particulate samples.

Parameters required to determine $\mathrm{k}$ accurately are shown in equation (1).

$\mathrm{Pv}=\mathrm{W} / \rho$

Where:

$$
\begin{aligned}
& \mathrm{Pv}=\text { solids volume, } \mathrm{m} 3, \\
& \mathrm{~W}=\text { mass of the aggregates, } \mathrm{kg}, \\
& \rho=\text { density of the aggregates, } \mathrm{kg} / \mathrm{m} 3 .
\end{aligned}
$$

The $V$ is the volume occupied by packed aggregate particles, as expressed in equation (2).

$\mathrm{V}=\mathrm{W} / \mathrm{M}$

Where:

$\mathrm{V}=$ compacted bulk volume, $\mathrm{m} 3$,

$\mathrm{W}=$ mass of the aggregates, $\mathrm{kg}$,

$M=$ compacted dry-rodded unit weight of the aggregates, $\mathrm{kg} / \mathrm{m} 3$.

Thus, $\mathrm{k}$ is the ratio between Pv and V (De Larrard, 1999) as seen in equation (3).

$\mathrm{k}=\mathrm{Pv} / \mathrm{V}$

Where:

$$
\begin{aligned}
& \mathrm{k}=\text { aggregate packing, } \\
& \mathrm{Pv}=\text { solids volume, } \mathrm{m} 3 \\
& \mathrm{~V}=\text { compacted bulk volume, } \mathrm{m} 3 .
\end{aligned}
$$

\subsection{Green Concrete}

Is it possible to reduce environmental damage caused by cement and concrete industries? In general, a great approach to minimize the environmental impact of using any natural mined resource is downgrading its consumption rate (Mehta, 2002).

Aggregates usually occupy 70 to $80 \%$ of the volume of Portland cement concrete, significantly dominating its mechanical and physical properties (Tasi, Li, and Hwang, 2005). The properties of the aggregates, proportioning and packing significantly affect the performance of concrete. Optimized aggregate blends may improve concrete performance and be an essential advantage to design concrete at lower cementitious material content levels (Moini et al., 2015).

North America and Europe are experiencing a population growth stabilization, while population growth is slowing down in South America, Africa, and Asia. The expectation is that in 2050 the world's population will be stable at approximately 10 billion. However, natural resources are likely to decrease in availability due to current high demand for new infrastructure, including roads and ports. Indeed, extracting raw materials is causing environmental degradation and, significant energy is required to mine, crush, and process operations (Khatibmasjedi, De Caso y Basalo, and Nanni, 2016; mehta, 2002).

The GHG emission level has a direct impact to the Earth's atmospheric layer, contributing to an increase of its opacity, with the potential of diminishing its capacity to release energy generated by the surface (Agopyan and John, 2011).

In detail, the Earth's surface absorbs the energy provided by the sun, turning it into heat or infrared energy. The heat is reflected on the Earth's surface, ascends and provides energy for the excitation of $\mathrm{CO} 2$ molecules in the atmosphere. Besides other molecules, $\mathrm{CO} 2$ acts as heat-reflector, redirecting the heat back to the surface of the Earth. This process can create warming effects on the planet (Rifkin, 1989).

For instance, $1 \mathrm{~g}$ of limestone decomposed in high-temperature furnaces can generate $0.81 \mathrm{~g}$ of $\mathrm{CO} 2$. Cement is composed of limestone and is the most used artificial material worldwide, which is also responsible for about $5 \%$ of the global CO2 emissions (Khatibmasjedi, De Caso y Basalo, and Nanni, 2016; mehta, 2002; Agopyan and John, 2011)

\section{MATERIALS AND METHODS}

\subsection{Materials}

The Fine Aggregate (FA) considered in this study was silica sand, the Intermediate Aggregate (IA) was the Miami Oolite Limestone \#89, and the Coarse Aggregate (CA) was the Miami Oolite Limestone \#57, all according to the ASTM C33-16e1 (ASTM, 2016), Specification for Concrete Aggregates.

The Portland cement Type I/II and Type V considered in this investigation had physical properties and chemical composition according to the ASTM C150-17 (ASTM, 2017), Standard Specification for Portland Cement.

\subsection{Research Methodology}

The objective of this study is to propose the reduction of cement content in concrete as a viable alternative to green concrete by filling voids in aggregate gradation with intermediate-sized particles. This study can add to current initiatives to reduce cement production environmental 
impacts. The first step of the methodological approach used in this investigation was to design concrete mixtures based on known aggregate proportions. Figure 04 presents the adapted mixture design procedure based on the ACl211.1 (ACl, 1991), Standard Practice for Selecting Proportions for Normal, Heavyweight, and Mass Concrete. Once mixtures with 0 and $25 \%$ cement reduction were selected (Antunes and Tia, 2018), the aggregate increase due to proportioning could be calculated as shown in Table 01. Following, bearing on cement content and estimated construction volumes the reduction in concrete costs could be calculated as shown in Table 02 and 03.

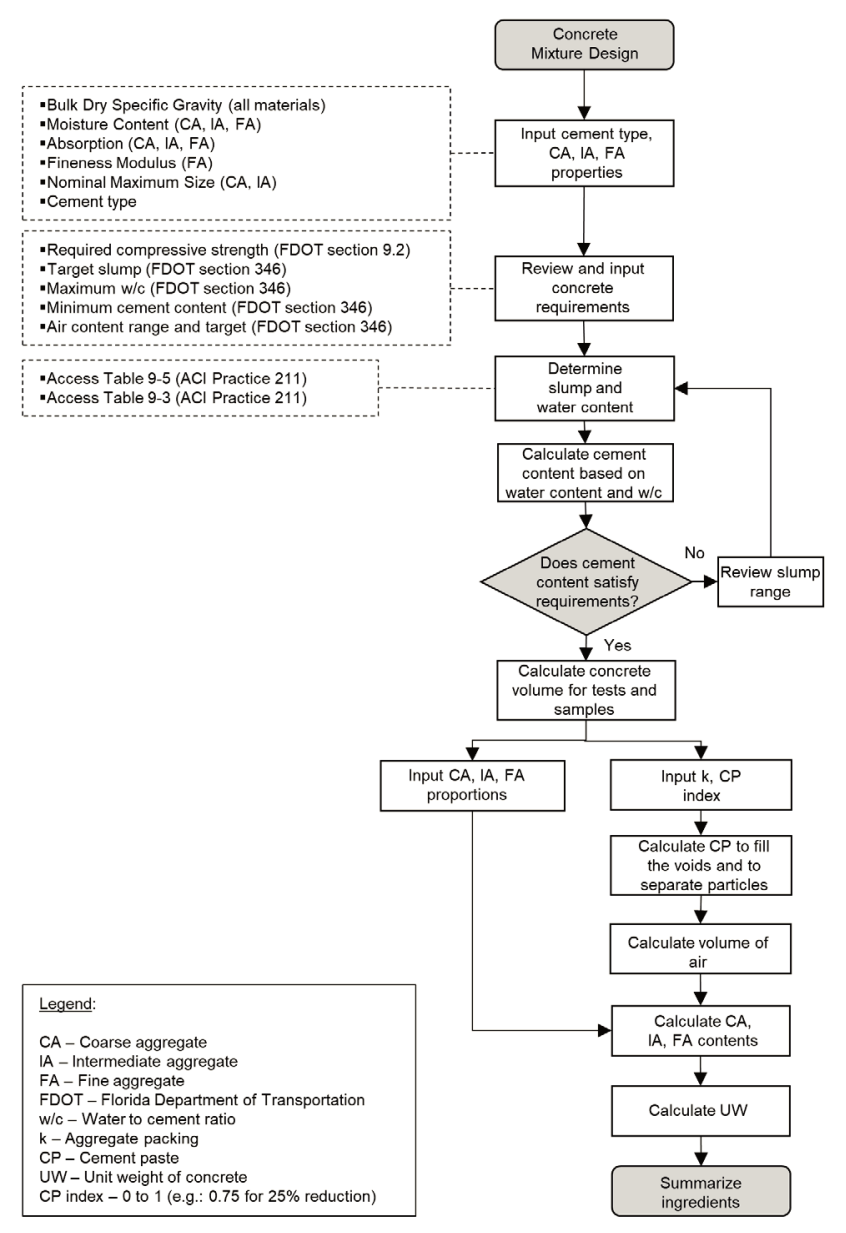

Figure 04 Fluxogram of the adapted concrete mixture design. Source: author.

\begin{tabular}{llllllll}
\hline Mix & $\begin{array}{l}\text { PC. } \\
\text { Red., } \%\end{array}$ & $\begin{array}{l}\text { Cement, Water, } \\
\mathbf{k g} / \mathbf{m}^{3}\end{array}$ & $\begin{array}{l}\text { CA, } \\
\mathbf{k g} / \mathbf{m}^{3}\end{array}$ & $\begin{array}{l}\text { IA, } \\
\mathbf{k g} / \mathbf{m}^{3}\end{array}$ & $\begin{array}{l}\text { FA, } \\
\mathbf{k g} / \mathbf{m}^{3}\end{array}$ & $\begin{array}{l}\text { CA + IA } \\
\mathbf{k g} / \mathbf{m}^{3}\end{array}$ \\
\hline 1 & 0 & 370 & 185 & 942 & 171 & 548 & - \\
2 & 25 & 279 & 139 & 1054 & 191 & 614 & 11,9 \\
3 & 0 & 534 & 267 & 1019 & 360 & 1019 & - \\
4 & 25 & 400 & 200 & 1133 & 400 & 1133 & 11,1 \\
\hline
\end{tabular}

Table 01 Concrete mixture design with the aggregate content increase due to cement content reduction.

\begin{tabular}{|c|c|c|c|c|}
\hline $\begin{array}{l}\text { Vol. } \\
\text { Concrete, } \\
10^{3} \mathrm{~m}^{3} \\
\end{array}$ & $\begin{array}{l}\text { Type Yll Cement } \\
\text { Content, } \mathrm{kg} / \mathrm{m}^{3}\end{array}$ & $\begin{array}{l}\text { Cement, } \\
10^{6} \mathrm{~kg}\end{array}$ & $\begin{array}{l}\text { Bulk } \\
\text { Cem., } \\
\text { usD/kg } \\
\end{array}$ & $\begin{array}{l}\text { Total, } \\
\text { Milion } \\
\text { USD } \\
\end{array}$ \\
\hline 718 & 370 & 266 & 0,12 & 31,9 \\
\hline \multirow[t]{2}{*}{718} & 279 & 200 & 0,12 & 24,0 \\
\hline & & & Difference: & 7,9 \\
\hline
\end{tabular}

Table 02 Cement cost reduction in concrete pavement construction.

\begin{tabular}{|c|c|c|c|c|}
\hline $\begin{array}{l}\text { Vol. } \\
\text { Concrete, } \\
10^{3} \mathrm{~m}^{3} \\
\end{array}$ & $\begin{array}{l}\text { Type V Cement } \\
\text { Content, kg/m }\end{array}$ & $\begin{array}{l}\text { Cement, } \\
10^{6} \mathrm{~kg}\end{array}$ & $\begin{array}{l}\text { Bulk } \\
\text { Cem., } \\
\text { uSD/kg }\end{array}$ & $\begin{array}{l}\text { Total, } \\
\text { Million USD }\end{array}$ \\
\hline 102 & 534 & 55 & 0,15 & 8,2 \\
\hline \multirow[t]{2}{*}{102} & 400 & 41 & 0,15 & 6.1 \\
\hline & & & Difference: & 2,1 \\
\hline
\end{tabular}

Table 03 Cement cost reduction in port construction.

\section{RESULTS AND DISCUSSION}

\subsection{Limestone Mining in Florida}

The production of Miami limestone for aggregate production has reached 55 million metric tons. Since a decrease of $25 \%$ in cement content in concrete requires an average $11.5 \%$ increase in aggregate content due to yield volume requirements, the increase in limestone content in concrete due to the reduction in cement content can drive limestone aggregate production in Florida to reach 61.3 million tons a year for concrete production alone.

\subsection{Concrete Cost}

There is a wide variety of engineering applications for concrete in transportation. Thus, several benefits can follow the cement consumption reduction. One example is that a $25 \%$ cement content reduction in concrete pavement can result in USD $11,04 / \mathrm{m} 3$ reduction in cement costs. In a construction of a 4-lane and $160-\mathrm{km}$ highway with the minimum concrete strength of $29 \mathrm{MPa}$ ( 28 days) as shown in Figure 05, approximately eight million USD may be saved in cement costs (Table 2).

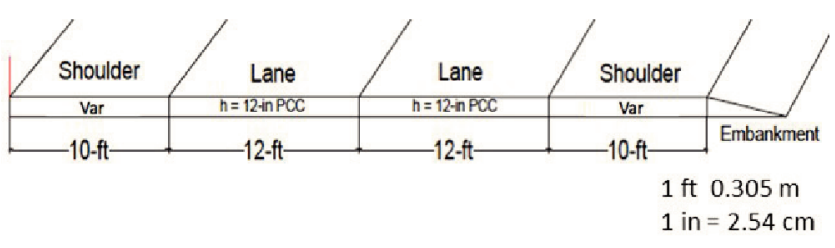

Figure 05 Cross-section of slip-formed concrete pavement (one direction). Source: author.

Seaports frequently require technical improvements for navigability, loading capacity, and to reduce the time spent to load and unload freight. Engineers typically 
specify $41 \mathrm{MPa}$ at 28 days concrete in compression, composed of $534 \mathrm{~kg} / \mathrm{m} 3$ of Portland cement (Larrossa, Real, and Dias, 2014).

Concrete is usually used in breakwater systems to protect channel entrances, in berths to increase vessels handling capacity, and in dry-dock bottom slabs to increase storage capacity. Tetrapods are required in breakwaters (Figure 06), comprising an estimated volume of 61.200 $\mathrm{m} 3$ of concrete. Pier structure is usually made of precast and reinforced concrete spanning for about $914 \mathrm{~m}$. Approximately $536 \mathrm{~m} 3$ of concrete are needed to cast circular piles with an outer diameter of $81 \mathrm{~cm}$, inner diameter of $51 \mathrm{~cm}$, and $610 \mathrm{~m}$ depth (Figure 07) (Larrossa, Real, and Dias, 2014). The slab considered in the calculations is a concrete structure of 130 by 335 by $0,90 \mathrm{~m}$ (40.000 m3).

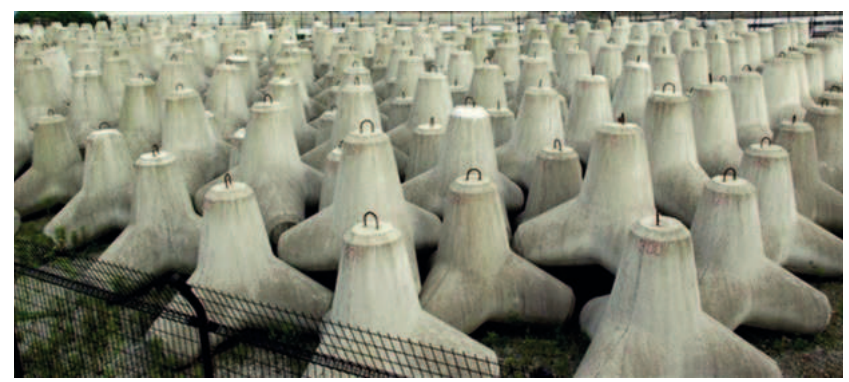

Figure 06 Tetrapods used in port breakwaters. Source: author.

Assuming tetrapods, pier, and slab use the same type of concrete, a total of $102.280 \mathrm{~m} 3$ would be required for this construction. Table 03 details that nearly two million USD would be saved in this project under a $25 \%$ cement content reduction in the concrete, resulting in a reduction of 20.10 USD per $\mathrm{m} 3$ of concrete in cement costs.

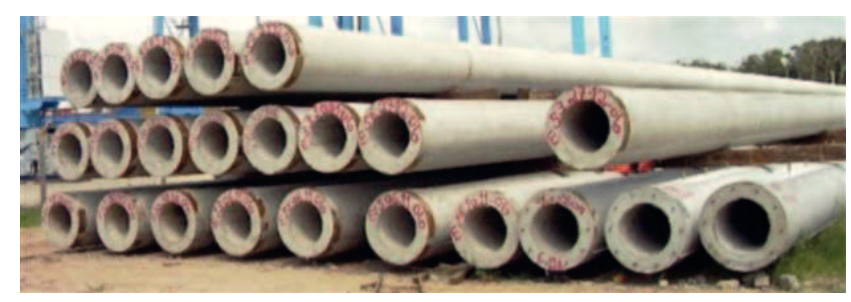

Figure 07 Piles for the pier.

Source: author.

\subsection{Reduction in $\mathrm{CO} 2$ Emission}

Cement is composed of about $60 \%$ Calcium Oxide (CaO) from limestone. The ASTM C150 (2017) does not require a minimum or maximum limit of $\mathrm{CaO}$ in the chemical specification of Portland cement. But, standard tests show that final products contain $62,9 \%$ of $\mathrm{CaO}$. According to
Agopyan and John (2011), $44 \%$ of the limestone consists of CO2, and the ASTM C150 (2017) requires that the limestone used to produce cement contain at least $70 \%$ of Calcium Carbonate ( $\mathrm{CaCO} 3)$ in its composition, although routine tests indicate a $79 \%$ content of $\mathrm{CaCO} 3$ in limestone. To put it another way, making $100 \mathrm{~g}$ of Portland cement would require $62,9 \mathrm{~g}$ of $\mathrm{CaO}, 112,3 \mathrm{~g}$ of $\mathrm{CaCO}$, and likely $160,5 \mathrm{~g}$ of limestone. Reducing cement content in $25 \%$ can result in a decrease of 80.000 and 17.000 tons of $\mathrm{CO} 2$ emission in pavement and seaport construction, respectively.

\section{CONCLUSION}

This study discussed the effects of the reduction of 25 $\%$ in cement content in concrete on $\mathrm{CO} 2$ emissions and cement budget, which has a significant impact on the current and future sustainability of cement production and concrete employed in business-as-usual construction such as pavements and seaports. Many advanced economies such as the U.S. must replace and upgrade long-neglected bridges, pavements, pipelines, transit systems, among other infrastructure.

The primary findings are:

1. Results show an $11,5 \%$ increase in limestone mining for concrete production alone, targeting South Florida sources.

2. Typical cement costs in concrete can be reduced in 11,04 USD per m3 of concrete for pavement and 20,10 USD per $\mathrm{m} 3$ for seaport construction.

3. A decrease of 80.000 tons of $\mathrm{CO} 2$ emission in a 160 $\mathrm{km}$ road segment (one direction), and 17.000 tons of $\mathrm{CO} 2$ in seaport construction might be obtained.

We have a timely opportunity to reduce the risk of climate change in infrastructure construction through innovations in aggregate optimization and packing techniques. These are inexpensive, significant and still not quite realized opportunities for advances in concrete design that can reduce the costs of built infrastructure.

On the one hand, the higher the concrete volume in construction, the more significant environmental benefit can be obtained by reducing cement content in concrete. On the other hand, the higher the designed cement per volume of concrete, the more budget savings in case of reduction in cement content. To conclude, an increase in aggregate mining is to be expected when concrete contains less cement in the composition, relation that merits further investigation. 


\section{ACKNOWLEDGEMENT}

Thanks to the Brazilian Coordination for the Improvement of Higher Education Personnel (CAPES) for financial support.

\section{REFERENCES}

New Climate Economy. The Global Commission on the Economy and Climate The Sustainable Infrastructure Imperative: Financing for Better Growth and Development. Washington, DC, USA, 2016.

KHATIBMASJEDI, s., De Caso y Basalo, F. J., and Nanni, A. SEACON: Redefining Sustainable Concrete, Fourth International Conference on Sustainable Construction Materials and Technologies. Las Vegas, NV, USA, 2016.

MEHTA, P. K. Greening of the Concrete Industry for Sustainable Development. Concr. Int., vol. 24, no. 7, 2002, pp. 23-28.

AGOPYAN, v. and John, V. M. O desafio da sustentabilidade na construção civil. Sao Paulo: Blucher, 2011.

AISSOUN, B. M., Hwang, S.-D., and Khayat, K. H. Influence of aggregate characteristics on workability of superworkable concrete. Mater. Struct., vol. 49, no. 1-2, 2016, pp. 597-609.

Latin America Conservation Council. Smart Infrastructure for Latin America. Arlington, VA, USA: The Nature Conservancy, 2015.

International Energy Agency. Energy Technology Perspectives: Scenarios \& Strategies To 2050. Paris, FR, 2008.

MEHTA, P. K. and Monteiro, P. J. M. Concrete: microstructure, properties, and materials. New York, NY, USA: Mc Graw Hill, 2006.

LINDQUIST, W., Darwin, D., Browning, J., McLeod, H. A. K., Yuan, J., and Reynolds, D. Implementation of concrete aggregate optimization. Constr. Build. Mater., vol. 74, 2015, pp. 49-56.

Mohammed, M. H., Emborg, M., Pusch, R., and KNUTSSON, S. Packing Theory for Natural and
Crushed Aggregate to Obtain the Best Mix of Aggregate: Research and Development. Proc. WASET Int. Conf. Civ. Constr. Eng. Stock. Sweden, 2012, vol. 6, no. 7,2012 , pp. 819-825.

MOINI, M., Flores-Vivian, I., Amirjanov, A., and Sobolev, $K$. The optimization of aggregate blends for sustainable low cement concrete. Constr. Build. Mater., vol. 93, 2015, pp. 627-634.

DE LARRARD, F. Concrete Mixture Proportioning: A Scientific Approach. Boca Raton, FL, USA: CRC Press, 1999.

TASI, C. T., Li, L. S., and Hwang, C. L. The Effect of Aggregate Gradation on Engineering Properties of High Performance Concrete. J. ASTM Int., vol. 3, no. 3, 2005, pp. 1-12.

RIFKIN, J. Entropy: into the greenhouse world. Madison, WI, USA: Bantam Books, 1989.

ASTM International. ASTM C33 / C33M-16e1: Standard Specification for Concrete Aggregates, ASTM International, West Conshohocken, PA, 2016.

ASTM International. ASTM C150 / C150M-17: Standard Specification for Portland Cement. West Conshohocken, PA, USA, 2017.

American concrete institute. ACl 211.1: Standard Practice for Selecting Proportions for Normal, Heavyweight, and Mass Concrete. Farmington Hills, MI, USA,1991.

ANTUNES, Rodrigo, and TIA, Mang. Influence of Intermediate-Sized Particle Content on Traditional Dry-Rodded and Vibrated Aggregate Packing. Int. J. Eng. Res. Appl, vol. 8, no. 4, 2018, pp. 21-27.

LARROSSA, M. C., Real, M. V., and Dias, C. R. R. Análise estatística e teste de conformidade do concreto de obras portuárias. Rev. IBRACON Estruturas e Mater., vol. 7, no. 3, 2014, pp. 468-482. 


\section{AUTHORS}

ORCID: https://orcid.org/0000-0002-1878-382X

RODRIGO ANTUNES, Ph.D. | University of Florida | Department of Civil and Coastal Engineering | Florida. United States of America | Correspondência para: University of Florida - Gainesville, FL 32611 | E-mail: rodrigo.antunes@ufl.edu

ORCID: https://orcid.org/0000-0001-9310-5722

MANG TIA, Ph.D. | University of Florida | Department of Civil and Coastal Engineering | Florida. United States of America | Correspondência para: University of Florida Gainesville, FL 32611 | E-mail: tia@ce.ufl.edu

\section{HOW TO CITE THIS ARTICLE}

ANTUNES, Rodrigo; TIA, Mang. Cement Content Reduction In Concrete Through Aggregate Optimization and Packing: A Sustainable Practice for Pavement and Seaport Construction. MIX Sustentável, [S.I.], v. 4, n. 3, p. 25-32, out-mar. 2018. ISSN 24473073. Disponível em: <http://www. nexos.ufsc.br/index.php/mixsustentavel>. Acesso em: dia mês. ano. doi:https://doi.org/10.29183/2447-3073. MIX2018.v4.n3.25-32. 